九州大学学術情報リポジトリ

Kyushu University Institutional Repository

\title{
Dharma Devices, Non-Hermeneutical Libraries, and Robot-Monks : Prayer Machines in Japanese Buddh i sm
}

Rambelli, Fabio

University of California, Santa Barbara : Professor of Japanese Religions and IFS Endowed Chair Shinto Studies

https://doi.org/10.5109/1917884

出版情報: Journal of Asian Humanities at Kyushu University. 3, pp.57-75, 2018-03. Kyushu University, School of Letters, Graduate School of Humanities, Faculty of Humanities バージョン:

権利関係 : 


\title{
Dharma Devices, Non- Hermeneutical Libraries, and Robot-Monks: Prayer Machines in Japanese Buddhism
}

\author{
FABIO RAMBELLI
}

$\mathrm{T}$ is a well-documented fact-albeit perhaps not emphasized enough in scholarship-that Japanese Buddhism, historically, often has favored and contributed to technological developments. ${ }^{1}$ Since its transmission to Japan in the sixth century, Buddhism has conveyed and employed advanced technologies in fields including temple architecture, agriculture, civil engineering (such as roads, bridges, and irrigation systems), medicine, astronomy, and printing. Furthermore, many artisan guilds (employers and developers of technology) - from sake brewers to sword smiths, from tatami (straw mat) makers to potters, from makers of musical instruments to boat builders - were more or less directly affiliated with Buddhist temples. In addition, numerous professions specialized exclusively in the production of Buddhist objects and developed

I would like to express my gratitude to An Pham-guoc, José Cabezón, Sabine Frühstück, Hannah Gould, Leor Halevi, George Hirshkind, Itō Satoshi, John Modern, Jennifer Robertson, Peter Romaskiewicz, Stefania Travagnin, and Vesna Wallace for their comments; suggestions from an anonymous reader for JAH-Q have significantly improved this article.

1 A lack of more comprehensive, intercultural studies of Buddhist attitudes toward technology, especially in Southeast Asia, makes it impossible to decide whether this is a constant feature of Buddhism in general or a Japanese cultural specificity. their technologies for that purpose. ${ }^{2}$ From a broader perspective of more general technological advances, it is interesting to note that a Buddhist temple, Negoroji 根来寺, was the first organization in Japan to produce muskets and mortars on a large scale in the 1570 s based on technology acquired from Portuguese merchants. ${ }^{3}$ Thus, until the late seventeenth century, when extensive epistemological and social transformations gradually eroded the Buddhist monopoly on technological advancement in favor of other (often competing) social groups, Buddhism was the main repository, beneficiary, and promoter of technology.

It should come as no surprise, then, that Buddhism also employed technology for religious and ritual purposes. Xylography is perhaps the most obvious example. Since the seventeenth century, the enormous development of the printing industry was fostered in part by temple presses and publishing houses related

See Rambelli, "Sacred Objects and Design in Buddhism."

See Conlan, "Instruments of Change," p. 124. While it is unclear whether the priests involved in that endeavor envisioned modern weapons as new forms of Buddhist tools, they may have thought that the capacity for a strong military defense would protect their temple from its enemies; in any case, their enemies proved stronger and better equipped, and the temple was destroyed by the army of warlord Toyotomi Hideyoshi 豊臣秀吉 (1537-1598) in 1585. 
to Buddhist organizations. Buddhists printed all kinds of materials, from prayers, scriptures, doctrinal texts, and commentaries to temple gazetteers, legends, histories, and hagiographies. This vast range of printed material was envisioned as a support for prayer activities. An important precedent, based on earlier Chinese and Korean models, existed for the printing of the early modern period (early seventeenth to mid-nineteenth century): around 770 the Japanese government ordered the printing of one million copies of a prayer (the socalled Hyakumantō darani 百万塔陀羅尼) to be placed inside miniature models of a pagoda and distributed to temples all over Japan. ${ }^{4}$ Although the printing of the Hyakumantō darani occurred within social and historical circumstances that were very different from those of the Edo period (160o-1868), this does suggest a strong interest, within Buddhist institutions, for technology and its possible religious uses.

Temple bells, musical instruments (such as the shakuhachi 尺八 flute, gongs, and drums), and ritual implements (including the vajra club and juzu数珠 rosary) were also envisioned as tools to convey prayers in non-linguistic forms. In fact, any number of mechanical devices can be turned into prayer machines, even toilets. ${ }^{5}$ In this context, "machine" refers to any device created in order to carry out specific tasks, one typically made of multiple parts and using some kind of power (physical, bodily, or mechanical), created in order to carry out specific tasks. In a premodern historical context, machines often were operated by human power (in some cases, also by natural agencies as with windmills and watermills, or animal force as with ploughs), and functioned in close symbiosis with the human body; as

4 See Kornicki, "The Hyakumantō Darani and the Origin of Printing in Eighth-Century Japan."

5 This is not an exaggeration. Present-day toilets at some Japanese temples function as machines to cleanse the impurities caused by human excrement by mobilizing the power of Ususama Myōō 烏枢瑟摩明王 (Sk. Ucchusmā vidyārāja). The user of the toilet is invited to chant or visualize the initial letter of Ususama's

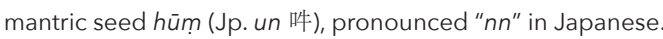
Now, the sound of defecation is normally rendered in the Japanese language as "nn," which therefore sounds the same as the mantra un. In this way, the sound of the polluting act is also the very cause of its purification; these two acts (polluting and purification) are thus deeply related by virtue of semiotic mechanisms centered on the mantra un, its sound, and its meanings (see Rambelli, A Buddhist Theory of Semiotics, pp. 136-37). All of this is made possible by the toilet, which changes its status from a mere practical tool into a veritable prayer machine. we shall see below, this is a significant difference with modern automated machines.

Concerning Buddhist "prayer," the English equivalent for contemporary Japanese terms such as kigan 祈願, kitō 祈祷, and inori 祈り, here it may be understood as any interaction, mostly and primarily verbal (or translatable in discursive terms), with one or more divine beings (buddhas, bodhisattvas, and other beings of the Buddhist pantheon), carried out for multiple purposes. Often a prayer is made to ask something of the divinity on behalf of oneself or others (this also includes so-called magic formulae), to express gratitude to the divinity, or to perform and display sentiments and acts of devotion. In certain Buddhist traditions, prayers also can be used as instruments or supports for visualization or, more generally, for actualizing the presence of the divinity. This is the case for mantras in Tantric Buddhism and repeated formulae such as the nenbutsu 念仏 (the praise given to the Buddha Amida 阿弥陀, a formula that actually started as a visualization practice) in the Pure Land sects and the daimoku 題目 (chanting of the title of the Lotus Sutra) in sects related to the teachings of the thirteenth-century monk Nichiren 日蓮 (1222-1282). Contemplative prayers involving visualizations of sacred realms also belong to this category. In all cases, prayer is believed to generate some form of merit ( $k u$ doku 功德), that is, religious virtue that not only can improve the karma of the practitioner but also can be transferred to others. The term "prayer" also may define a ritual that includes prayer as defined above. Prayers do not need to be voiced: even when the prayer is silent or meditative (such as when no specific words or, in extreme cases, even well-formed thoughts are present), silence can be configured as a semiotic system different from, and superior to, speech in matters of communication with the divinities. A prayer can be performed by an individual or a group, either by following established procedures (rituals, liturgies, or ceremonies) or by "improvising” ritual acts. Moreover, a prayer can be performed directly by the practitioner or by mediators such as monks, priests, and ritual specialists in charge of defining the appropriate words and procedures for the prayer, and often leading the proceedings. In some cases, a prayer (both text and ritual procedure) is claimed to have originally been revealed directly by a divinity. Finally, a prayer can be extemporaneous (only done when needed) or performed at regular, specific times defined by liturgical calendars (nenjū gyōji 年中行事). 
This essay will present and discuss the little-known subject of the presence, in the Japanese Buddhist tradition, of machines (special tools and other mechanical devices) used for the production and proliferation of prayers and prayer-related activities, their status within the Buddhist cultural system, and the conceptual challenge that they pose to issues of individual agency, religious practice, and, ultimately, soteriology.

\section{Buddhist Prayer Machines}

Even a cursory search of online sites selling Buddhist objects and implements yields an impressive list of artifacts, including Tibetan prayer wheels powered by solar energy, software with mantra-chanting loops to be installed on computers, loop machines chanting continuously the invocation to the Buddha Omituo 阿弥 陀仏 (Sk. Amitābha) in Taiwan, even a wallet with an automated scripture-chanting chip that activates when opened. Ritual services involving technology include internet rituals in China and elsewhere, and Buddhist TV rituals in Taiwan. ${ }^{6}$ All of these machines and machine-based services ostensibly are sold as ways to promote and facilitate Buddhist practice; many are created, used, and promoted by Buddhist organizations.

Some of these devices may appear exotic if not even far-fetched, more like souvenir-shop curios than prayer devices, or even as technological degenerations away from the true, spiritual purpose of Buddhism. Indeed, many observers and practitioners, especially in the West, cling to an image of Buddhism as a purely spiritual religion, unburdened by objects and hardly needing any ritual. Yet Buddhism throughout history has been characterized by the important role played by materiality, understood as both a system of objects and as philosophical speculations on them. To begin with, the Buddhist ideal of renunciation was predicated upon material objects and worldly attitudes to be abandoned; Buddhist rituals require a wide variety (and, not infrequently, vast amounts) of items (such as sacred images, scriptures, ritual implements, and offerings); large monastic organizations need numerous kinds of materials, commodities, and services, some of which have been sacralized (transformed into direct

6 For internet rituals, see Travagnin, "Cyber-Activities and 'Civilized' Worship." manifestations of the sacred); and the diffusion and success of Buddhism in general has required many types of material things, including books, images, implements, tools, documents and certificates, maps and instructions, furniture, food, flowers, incense, clothes, vehicles, and countless other items ${ }^{7}$ Still, it is somewhat surprising to find machines, and especially prayer machines, among the stuff that made Buddhism what it is, not only today but also in premodern Asia.

The realization that machines, including prayer machines, have been an important part of the Buddhist cultural system challenges received perceptions (widespread mainly in the West and dating back to the early modern period) about Western technological superiority to other countries, on the one hand, and the separation of science and technology from the sphere of the religious, on the other. ${ }^{8}$ With Buddhism, we have a major religion actually promoting technological developments also for religious, salvific purposes.

A full treatment of the entire spectrum of Buddhist prayer machines throughout history and across cultures goes far beyond the scope of this essay. Here, the focus will be limited to a few representative instances of prayer machines from the Japanese Buddhist tradition, both premodern and modern. They are, in order of increasing mechanical complexity, the shakuhachi, prayer wheels and rotating sutra repositories, early modern mechanical devices (karakuri からくり or 機巧), and recent digital technologies such as robot priests. We shall see how each of these devices contributed to promoting novel and specific ways to "pray" and spread Buddhism. Next, the semiotic status of those prayer machines as special devices for disseminating signifiers associated with Buddhism and its teachings will be evaluated. Finally, the relationship of these prayer machines to Buddhist doctrines on materiality, practice, and salvation will be assessed.

\section{- Shakuhachi Flute}

The shakuhachi is a vertical flute, made of one single piece of bamboo with five holes (four in front and

\footnotetext{
7 Whereas all religions require material objects, it may be argued that the sheer amount of material objects and the vastness of their presence in Buddhist practice set Buddhism apart from most religious traditions.

8 On this subject, see Adas, Machines as the Measure of Men.
} 
one in back), measuring approximately one foot, eight inches (about $54.5 \mathrm{~cm}$ ). It was brought to Japan around the seventh or eighth century as one of the instruments used for court music (gagaku 雅楽), but at the time it was not widely played and eventually fell into oblivion. The shakuhachi as we know it today began to be used in the early Edo period (early seventeenth century) by monks belonging to a newly formed and elusive Zen sect, the Fukeshū 普化宗, to which the Japanese government granted exclusive use of the instrument.

Musical instruments, especially relatively simple wind instruments such as the flute, normally are not considered machines. Buddhist monks treated the shakuhachi, however, as a peculiar device, made with specific technologies, that employed musical techniques in order to spread the Dharma in its unique ways. According to governmental regulations, the shakuhachi could not be played in public performances of a non-religious nature, but was only to be used by Fuke monks (known as komusō 虚無僧) in meditation and other rituals as their unique Dharma device (or Dharma instrument, hōki 法器). Because the komusō did not have a public to please, they were relatively free to develop new playing techniques and musical forms, which constituted the bases of today's shakuhachi music. ${ }^{9}$ In addition, the Fuke sect came to develop what can be considered the first meditative instrumental music of the entire Buddhist tradition, much before contemporary New Age music. For the komusō, playing the shakuhachi amounted to practicing Zen; their quest for the absolute and ultimate sound (tetteion 徹底音) aimed at attaining enlightenment (satori 悟り).

As mentioned above, for the komuso the shakuhachi was not just a musical instrument, but a veritable Dharma device (hōki). This term, literally meaning "Dharma vessel," has a broad semantic range. Normally it refers to a worthy recipient of the teachings, as in the case of the best disciples of a Buddhist master. Yet "vessel" also may refer to "material objects," as in the expression "realm of material objects" ( $k i k a i$ 器界 or kisekai 器世界), with a special connotation indicating tools and ritual implements. Because of its nature as a ritual implement made specifically to express the Dharma and attain awakening, the shakuhachi came to

9 See Gurtzwiller, "Shakuhachi: Aspects of History, Practice and Teaching"; Gurtzwiller, Die Shakuhachi der Kinko-Schule; Johnson, Shakuhachi: Roots and Routes. be sacralized and eventually turned into a sort of mandala, a microcosm that embodies all of the fundamental forces and components of the entire Buddhist universe. Throughout the early modern period, the Fukeshū produced doctrinal documents in which the mandalic nature of their instrument, their music, and their playing style was defined and explained. What follows is a brief summary of their instrumental and musical doctrines.

Mandalization began with the very name and shape of the instrument itself (in analogy with the Esoteric Buddhist interpretations of mantras and other texts, which focused on the terms and the shapes of the objects to which they referred). Thus, shaku 尺 (one foot) was taken to represent the nature of awakening, whereas hachi 八 (eight [inches]) stood for the eight types of mind (hasshiki 八識) in Buddhist epistemology. The empty bamboo tube out of which the instrument was made was seen as the supreme Dao of vacuity (kyomu shidō 虚無至道), while the three nodes on the bamboo represented either the three components of the Confucian world (heaven, earth, and mankind; ten chi jin 天地人) or the three realms of the Buddhist cosmos (the realms of desire, forms, and formlessness, unified by the single, universal, and pure mind, or yuishin 唯 心). The two openings on the top and bottom of the instrument were seen as the sun and the moon, heaven and earth, and the two fundamental mandalas of Esoteric Buddhism. The five fingering holes represented the five elements (gogyō 五行) of Chinese cosmology (wood, metal, fire, water, and earth), or, in certain interpretations, a number of different sets of correlative series of cosmic elements: the five cakra centers of the body and the universe (gorin 五輪), the five musical modes (gochō 五調), the five Chinese elements of reality $(g \circ g y \bar{o})$, the five fundamental sounds of the pentatonic scale (goon 五音), or the five buddhas at the center of the mandala (Sk. Sākyamuni, Jp. Shaka 釈迦; Sk. Ratnasambhava, Jp. Hōshō 宝生; Sk. Mahāvairocana, Jp. Dainichi 大日; Sk. Amitābha, Jp. Amida; and Sk. Akṣobhya, Jp. Ashuku 阿閃), all of which are envisioned together as the origin and the condensation of the totality of phenomena (shinra banshō 森羅万象 or banbutsu 万物). ${ }^{10}$

10 In this regard, the shakuhachi was similar to other professional tools that were sacralized in different forms and to different extents by their users (such as the scale for merchants or the axe for carpenters); see Rambelli, "Honji Suijaku at Work"; Rambelli, Buddhist Materiality, pp. 172-210. 
Concerning musical practice, the Fuke sect taught that the breath running through the empty bamboo tube transcends all dichotomies, and that each melody is a manifestation of the absolute silence of enlightenment. The komuso playing the instrument did so not for individual pleasure, but as a way to enable listeners to understand that the forms are not different from mind (shiki soku shin 色即心), and as a way to attain Zen samādhi (zenjō zanmai 神定三昧), understood as a spiritual state of fusion between the self and the universe (banbutsu yo ga yūmei 万物與我幽冥). In this way, shakuhachi music served as a means to attain liberation from delusion, or nirvana (jakujō mui chi 寂静 無畏地). ${ }^{11}$

In the case of the shakuhachi, thus, a musical instrument is used as a Buddhist device to propagate the Dharma in a different form from verbal or visual dissemination, through manipulation of sound and silence, in ways that the human body alone cannot do. The status of the shakuhachi and its music does not depend only on the semiotic substance (sound and music) that they employ. Rather, shakuhachi music enables performers and listeners alike to represent and envision alternative ways to understand, practice, and experience Zen. Specifically, strategies of doctrinal encoding (mandalization) turned the instrument into a mandala or microcosmic device, and composition and performance techniques were correlated with particular doctrinal elements (such as nondualism and enlightenment). In other words, the shakuhachi became a prayer machine because, once the semiotic system associated with performance techniques and aesthetic principles was mastered, playing music on it enabled the player to "pray" and practice Buddhism in ways that would not have been possible with other tools/machines - or, indeed, without them.

\section{- Prayer Wheels and Rotating Sutra Repositories}

One of the most peculiar and conceptually interesting forms of Buddhist scripture worship is certainly the use of rotating sutra repositories (figure 1, an example from Kegonji 華厳寺, Ibigawa-chō 揖斐川町, Gifu Prefec-

11 Based on documents quoted in Takahashi, Fukeshū shōshi, pp. $59,60,61,62,64$; see also 187-88. ture). Known in Japanese as rinzō 輪蔵 (abbreviation of tenrinzō 転輪蔵, literally, “revolving [sutra] repository"), these devices consist of a sort of multisided (normally, octagonal) bookcase, with shelves on all sides, placed on a rotating axis; the bookcase contains sutra scrolls of the entire Buddhist canon. The invention of this device is attributed to $\mathrm{Fu} \mathrm{Xi}$ 伏䓫 (497-569), an eccentric Chinese religious figure also known as $\mathrm{Fu}$ Dashi 伏大士 (Bodhisattva Fu; Jp. Fu Daishi), who was worshiped as a manifestation of Maitreya, the buddha of the future. ${ }^{12}$ Rotating sutra repositories were brought to Japan by Zen monks in the late fourteenth century; one of the oldest existing rinzō, built in 1408 (Ōei 応永 15), is located inside the Sutra Hall (Kyōdō 経堂) at Ankokuji 安国寺 in Takayama (Gifu Prefecture in central Japan), and is designated by the Japanese government as a National Treasure. ${ }^{13}$

A noh play attributed to Kanze Nagatoshi 観世長 俊 (ca. 1488-ca. 1541), entitled Rinzō, describes a traveling monk's visit to the rotating sutra repository at Tenmangū 天満宮 Shrine-temple in Kitano, Kyoto. At the sacred site, the god of fire (Sk. Agni, Jp. Kajin 火神) and the spirit of Fu Dashi appear to the monk, and tell him that by turning this device he can, in fact, pay homage to the entire Buddhist canon. ${ }^{14}$ This drama points to the novelty and exoticism of the device to the Japanese audience in the early sixteenth century. In the early seventeenth century, these devices spread beyond Zen institutions to temples of other sects as well. At that time, many large temples in big cities and regional centers, which owned the entire Buddhist canon, also built rotating sutra repositories. Rinzō provided a way for these temples to display their prestige (owning the entire Buddhist canon was a rare and great privilege, strengthened by the novelty of the rotating repository), while at the same time enabling them to share the canon with the illiterate and semi-literate masses, to many of whom the sutras were accessible only through this device.

In some cases, the rotating sutra repository was used

12 In fact, the first reference in China concerning revolving bookcases used for sacred texts dates from the ninth century, but such devices became very popular and widespread only during the twelfth century. On the history of the prayer wheel in China, see Goodrich, "The Revolving Bookcase in China."

13 The version of the Buddhist canon stored inside this bookcase was printed at a temple in Hangzhou during the Yuan dynasty (1271-1368).

14 Rinzō, in Sanari, ed., Yōkyoku taikan, vol. 5, pp. 3373-84. 


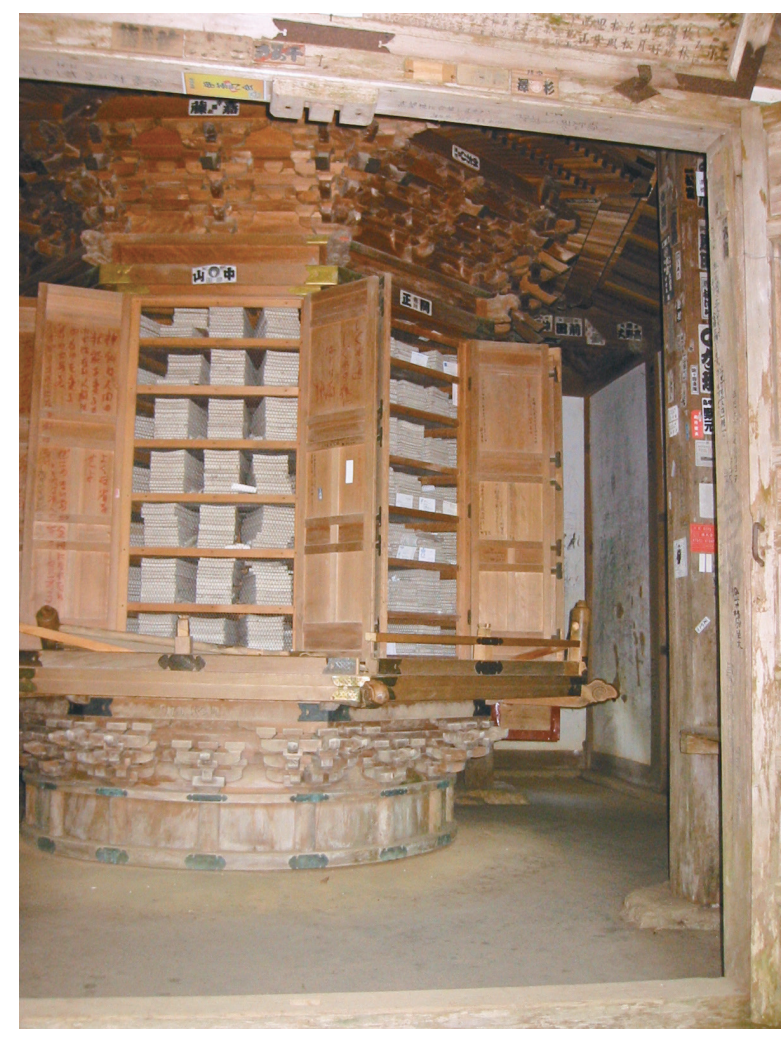

Figure 1. Rotating sutra repository (rinzō). 1902. Wood and metal. Size unknown. Kegonji, Ibigawa-chō, Gifu Prefecture. Public domain; https://ja.wikipedia.org/wiki/\%E8\%BC\%AA\%E8\%94\%B5\#/media/ File:Gifu-kegonji5738.JPG.

to worship its putative inventor, Fu Dashi, whose statue is sometimes enshrined in front of the device, alone or with other saintly figures. For example, the rotating sutra repository at Zenkōji 善光寺 in Nagano (central Japan) enshrines the two Japanese patriarchs of the Tendai 天台 sect, Saichō 最澄 (Dengyō Daishi 伝教 大師; 767-822) and Ennin 円仁 (Jikaku Daishi 慈覚大 師; ca. 793-864), together with Fu Dashi. The technical principle of the rotating sutra repository was also applied to other devices. For instance, the Rokkakudō 六 角堂 (Hexagonal Hall) at Mizusawadera 水沢寺 (Shibukawa, Gunma Prefecture), built in 1787, enshrines a very unusual rotating device with six statues of the bodhisattva Jizō 地蔵菩薩, one for each of the six destinations of transmigration (the realms of hell, hungry ghosts, animals, demigods, humans, and deities), as a way to represent both the process of reincarnation and the all-pervading salvific power of the bodhisattva.

Japanese and East Asian rotating sutra repositories appear to be variants of devices, commonly known as "prayer wheels," that are particularly popular in Tibet. Gregory Schopen has suggested that both may be derived from some kind of device used in India toward the eleventh century, but the evidence is inconclusive. ${ }^{15}$ Whereas Japanese rinzo are large devices containing the entire Buddhist canon, however, Tibetan prayer wheels are rotating cylinders of various kinds and sizes, upon which only one mantra normally is inscribed (most often, the mantra Om maṇi padme hüṃ).

Westerners came in direct contact with rotating prayer devices in various parts of Central and East Asia from around the nineteenth century. Several decades ago, however, historian of technology Lynn White Jr. suggested that European religious prohibitions against taking Christian slaves issued in the fifteenth century led slave traders to enslave people from Central Asia, some of whom might have brought along with them aspects of prayer-wheel technology. Indeed, the belland-chain governor (from hand-held wheels), the vertical-axis windmill (from wheels turned by wind), and the hot-air turbine (from wheels turned over fireplaces) were found in Renaissance Italy. ${ }^{16}$ If this thesis is correct, it would confirm both Buddhism's interest in technology and, at the same time, the fact that technology in the West was not directly related to religious practices but was used mostly for practical, secular endeavors.

Not much doctrinal or exegetical material regarding the prayer wheel seems to exist in China or Japan. In Tibetan Buddhism, however, where these devices are widely used, we can find a detailed theoretical treatment. ${ }^{17}$ The Tibetan tradition states that the great Indian scholar and Buddhist patriarch Nāgārjuna (ca. $150 \mathrm{CE}$ ) found the prayer wheel in the land of the nagas (mythological serpents) and transmitted it to a dākini (a demi-god, very important in Tantric Buddhism), who in turn handed it down to Padmasambhava, the founder of Tibetan Buddhism. ${ }^{18}$ Yet not much is known about actual historical processes of transmission of this device to Tibet. Some authors argue that a prayer wheel

\footnotetext{
15 Schopen, Figments and Fragments of Mahayana Buddhism in India, pp. 345-49; see also Goodrich, "The Revolving Bookcase in China," pp. 130-65

16 White, Medieval Religion and Technology, pp. 49-50.

17 For a selection of Tibetan commentaries on the prayer wheel, see Ladner, The Wheel of Great Compassion, pp. 33-84. 18 lbid., pp. 36, 47-48, 55.
} 
embodies all the actions of the buddhas and bodhisattvas of the ten directions. To benefit sentient beings, the buddhas and bodhisattvas manifest in the prayer wheel to purify all of our negative karmas and obscurations and to cause and actualize awakening. All beings - not only humans but also animals and insects - in the area where the prayer wheel is built are saved from rebirth in the lower realms. ${ }^{19}$

This salvific power seems to derive from the fact that prayer wheels contain the powerful mantra Om mani padme hüm, which embodies the buddhas and their virtues. Thus, touching or turning a prayer wheel puts the practitioner directly in contact with that powerful mantra and, by extension, with all of the buddhas and the benefits they generate. The salvific effects of the wheel are magnified when it comes into contact with the natural elements (earth, water, fire, and wind), because then the wheel's benefits are transmitted to the elements, which carry and spread them throughout the universe. ${ }^{20}$

Tibetan Buddhism also has developed visualization techniques centered on the prayer wheel. The first visualization describes a centrifugal process in which light emitting from the mantra in the prayer wheel is visualized; this light permeates the world and purifies it by sweeping away all negative karma. The second visualization is about a centripetal process in which the light emitting from the wheel's mantra absorbs and eliminates all negative elements. ${ }^{21}$

William Simpson, one of the first Westerners to study the prayer wheel (focusing mostly on its Tibetan versions), pointed to its main function as a merit-making device. As he wrote,

according to the Buddhist doctrine of Karma, or good works, the more a wheel is turned, the more Karma, or merit, is acquired by the person who causes it to turn; and from this it may be assumed that in the case of the cylinders propelled by wa-

19 Quoted in ibid., p. 37

20 See also ibid., pp. 48-50. Some of the semiotic strategies in which mantras are deemed effective in Tantric Buddhism, with special focus on the Japanese Shingon tradition, are discussed in Rambelli, A Buddhist Theory of Semiotics, especially chapter 4.

21 Ladner, The Wheel of Great Compassion, p. 39. ter-wheels, the constant turning would add to the merit of those connected with their erection. ${ }^{22}$

Simpson also indicated that merit-making does not result from a mere mechanical act of putting the wheel in motion, but involves the chanting of the mantra $\mathrm{Om}$ mani padme hüm, often inscribed in Tibetan prayer wheels: "Before turning the wheels, the performer should repeat the Mantra, else he will derive no merit from it; while he is turning, he may repeat the words as often as possible, and at the end a repetition is necessary, or the whole of the performance will be useless." ${ }^{\prime 23}$ In any case, Simpson described here the two ends of the spectrum of the functions of prayer machines, from a situation in which merit is accrued without further need of human intervention to cases in which humans must at least operate the machine and/or chant a mantra while doing so.

Regarding China, an account of the practice of a revolving Dharma repository at Wutaishan 五台山 given by a Western traveler toward the end of the nineteenth century suggests that "those who turn this ponderous cylinder believe that they acquire as much merit by the act as if they read all the books [contained in the device], repeated the prayers, and knocked their heads on the ground before all the gods whose images are enshrined in the wheel." ${ }^{24}$ Miss Gordon Cumming, a Western traveler to China and Japan during the same period, reports the presence of revolving Dharma repositories, which she calls "Scripture-Wheels," at many temples, but they were kept inside closed buildings and rarely used..$^{25}$

In Japan, it is said that by making this apparatus rotate, an amount of merit equivalent to that produced by actually reading the scriptures would be acquired. This was clearly a ritual act, as indicated by the fact that, in premodern times, people turned the prayer wheel while chanting the nenbutsu.

We can clearly see a continuity in both action and significance between Tibetan prayer wheels and Sino-Japanese rotating sutra repositories: the action sets in motion a rotating device, the function of which is understood as the generation of merit; merit is in turn explained as being produced by the power of the sa-

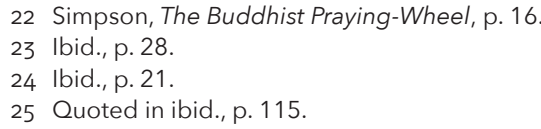


cred words (either mantras or entire scriptures) carried by those devices. In the specific case of sutra repositories, we do have indirect contact with the sutras (touching the shelves where they are placed), but none of the actions we usually attribute to "reading" (even if we understand this action in a very broad sense); the scriptures themselves are not even touched. And yet, this practice is supposed to produce merit. How can we explain its underlying logic?

The efficacy of the prayer wheel seems to be based on the complex semiotic drift of an influential Buddhist image, the "turning of the wheel of the Dharma," which originally referred to the Buddha preaching the Dharma. Rhys Davids, almost a century ago, explained that this expression should be understood as referring to "the setting in motion onwards of the royal chariot-wheel of the supreme dominion of the Dhamma," which means "the inauguration, or foundation, of the Kingdom of Righteousness." 26 In prayer wheels, we observe a metaphor (the expression "turning of the Dharma wheel" as referring to the Buddha's preaching and, by extension, to spreading Buddhism) being taken literally and made into a blueprint for mechanical devices. In these rotating objects (wheels), often incorporating the shape of the Indian cakra wheel (to reinforce their meaning), placed at temples or other religious sites to be used by pilgrims and devotees, parts - if not the totality of the Dharma (individual mantras or the entire canon)-literally are "turned" to indicate the spread of Buddhism and its efficacy. As such devotional operations involve manipulation of Buddhist sacred objects, they are considered to be highly meritorious and, by extension, to contribute to the diffusion of Buddhism.

Later, an additional layer of signification was added to these devices, as the rotating apparatus came to contain written mantras and even entire Buddhist scriptures. The new implication is that the actual turning of the entire apparatus carrying the scriptures, or of its components inscribed with sacred writings, would spread those sacred words into the air. In this case, the Buddha's speech has been transformed into writing, but the Dharma wheel presupposes the idea that writing can be spread through the air similarly to speech. "Dharma" is understood here as "scriptures," "wheel" is the revolving bookcase, and "turning" is the actual performance of the ritual. In other words, rinzō is a rit-

26 Quoted in ibid., p. 52. ual device that bases its efficacy on Buddhist scriptures while at the same time making their "reading" completely unnecessary.

Despite these operational and functional similarities, prayer wheels and rotating sutra repositories also show important differences in technological structure and economic scale. The former is a relatively small object, easy to build and carry; the latter is a large device, which cannot be moved, the construction of which requires specific skills and huge investments. In this respect, we can see why rotating sutra repositories were considered tokens of prestige for the temples owning them. ${ }^{27}$

\section{- Early Modern Automata and Mechanical Devices}

Japan has a long history of fascination with automata and clockwork mechanisms. Legends dating back several centuries tell of magicians or master carpenters creating mechanized humanoids to help them in construction work - veritable "robots" (laborer-automatons) ante litteram. In most versions of these legends, the automata eventually were discarded after the job was completed, but they continued to live; they married human females and raised progeny, whose descendents became some of the leading families of carpenters in premodern Japan..$^{28}$

The technology of automata flourished during the Edo period, when a number of artisans and professionals began to specialize in producing automated devices, known as karakuri in Japanese. Typically, karakuri were moving dolls carrying cups of tea or sake, but we also find walking or horse-riding dolls, dolls playing a drum, and pairs of animated puppets performing plays. Artisans also built clocks and clockwork models of the earth, and even of the Buddhist world centered on Mt. Sumeru. ${ }^{29}$

A stunning example of an automated puppet, dating

27 For a fascinating study on rotating sutra repositories in Japan, addressed from a different perspective than that discussed here, see Eubanks, "Circumambulatory Reading."

28 See Rambelli, Buddhist Materiality, pp. 177-78.

29 For a study of premodern Japanese automata, see Tatsukawa, Karakuri. On clockwork representations of Mount Sumeru, see Rambelli, "Sada Kaiseki: An Alternative Discourse," pp. 104-42; Rambelli, "Visions of the Invisible: Images and Representations," pp. 132-43. 
from the late eighteenth century and still functioning today, is a representation of the monk Hotei 布袋 on a stage (called Hoteidai 布袋台). ${ }^{30}$ With two acolytes (dōji 童子) flying above him, Hotei performs various movements for about fifty minutes until the fan he holds in his left hand opens up to reveal the religious message wakō dōjin 和光同塵 (“dimming one's radiance and becoming one with the dust of the secular world"), a passage originally found in the ancient Chinese classic

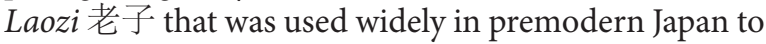
refer to the way in which divinities appeared and intervened in this world. This mechanical device was used at temple festivals. ${ }^{31}$

A karakuri catalogue of 1757 (Hōreki 宝暦 7), entitled Ökarakuri etsukishi 大からくり絵尽, authored by Nishimura Shigenaga 西村重長 (1697-1756), includes an image of the tainai totsuki no zu 体内十月 図 ("image of the ten months inside the womb"), also known as tainai totsuki henge 体内十月变化 (“transformations in the ten months inside the womb"). It represents the development of the baby inside the womb during the ten months of gestation, overlooked by ten Buddhist divinities (from Fudō 不動 to Amida), one for each month (figure 2). The conceptual framework for this device is based on medieval embryology and the cult of the ten buddhas (in itself, a variation of the cult of the thirteen buddhas), as described in texts such as Sanken itchisho 三賢一致書 (1649) by Dairyū 大龍 (n.d.).

According to Furukawa Miki, Buddhist priests used this device as a ritual implement to explain gestationand, additionally, the cycle of life and reincarnation. Furukawa reports a typical sermon as follows:

The woman's jade gate is the origin of the three worlds. All ornaments of the buddha-body are tools ( $d \overline{o g} u$ 道具) abiding inside women's wombs. If pulled apart they become Buddhist ritual implements, if kept together they stay inside the womb as women's tools. The shape of the fetus in the first month, and in general the shape of the human being when it is born, they all arise from this staff (shakujō 錫杖).

\footnotetext{
30 Hotei (Ch. Budai) is commonly known in the West as "laughing Buddha" or "fat Buddha"; he is a figure of early modern Chinese folk religion who also became popular in Japan.

31 See Tatsukawa, Karakuri, pp. 59-61.
}

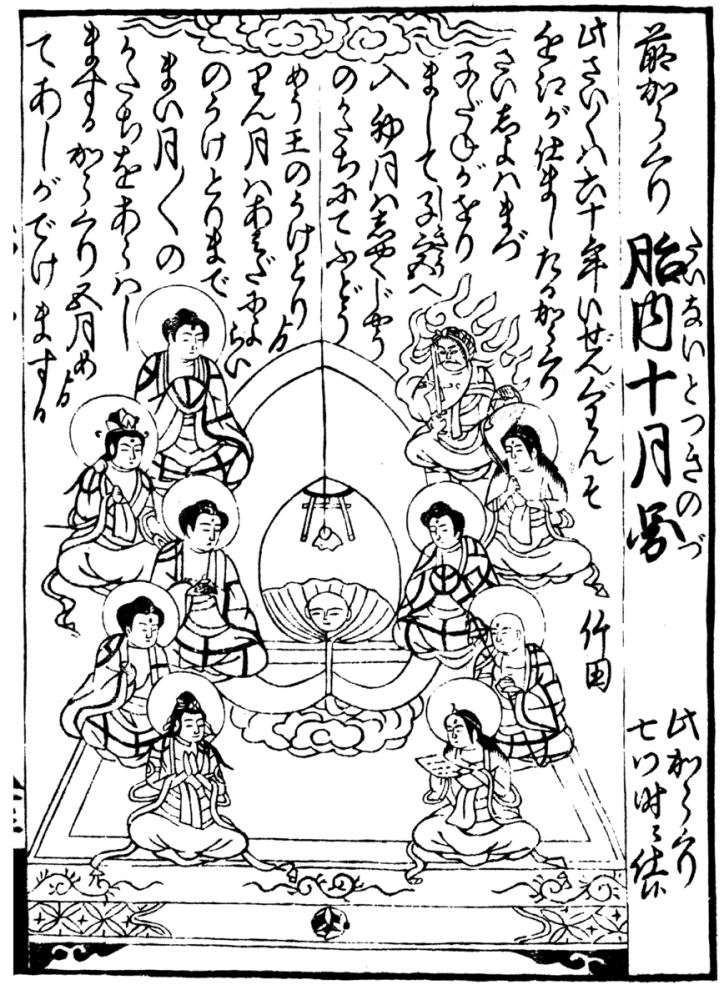

Figure 2. Tainai totsuki karakuri (mechanical device representing the fetus's transformations inside the womb). From Nishimura, Ōkarakuri etsukushi, vol. 2, p. 5. Courtesy of the National Diet Library, Tokyo.

This statement was followed by explanations of the two mandalas of Esoteric Buddhism, the existence of a lotus in the body corresponding to the heart, and a narrative about a spear (man) placed in the sea (woman) until it reaches the lotus (vagina) at the bottom; when that happens, after ten months a baby is born. ${ }^{32}$

One of the last of these devices is reported in Asakusa in $1862 .{ }^{33}$ This type of Buddhist-inspired karakuri, very popular in the Edo period, suggests the need for further study on early modern prayer machines and Buddhist attitudes toward technology.

32 Furukawa, Zusetsu shomin geinō, pp. 185-86.

33 Toward the end of the Edo period, this type of device inspired other karakuri related to sex and pornography; see Kinoshita, Bijutsu to iu misemono, p. 102. 


\section{- Robot Monks and Virtual (Online) Services}

These premodern precedents can perhaps contribute to explaining the Japanese interest in technological gadgets and, recently, in robots, as well as the fact that Japan is the country where the most advanced research in robotics is carried out. ${ }^{34}$ In recent years, robots have also surfaced in religious settings. A robot monk welcomes visitors to Hōtokuji 報徳寺 in the city of Kakogawa, Hyōgo Prefecture, in central-western Japan. It normally sits still and silent in meditation (zazen 座禅) position, with a rosary (juzu) in its left hand, but when a sensor detects a visitor in the temple hall, the robot automatically begins chanting a Buddhist scripture while striking the mokugyo 木魚 (literally, “wooden fish”), a percussion instrument used in Buddhist ceremonies. This robot monk, built out of recycled material, is a low-tech device, closer to a doll than to a full-fledged robot. The resident priest of the temple found that the parishioners actually like the robot monk, who has become a sort of "temple mascot." 35

A very recent and more developed version of a robot monk is an adaptation of Pepper ペッパー, SoftBank Group Corp.'s humanoid robot. Since the summer of 2017, a specially programmed variety of Pepper is able to recite sutras from four major Japanese Buddhist denominations; it is mostly intended to perform accompanying a human priest. This robot monk is now available to chant Buddhist scriptures at funerals for a significantly cheaper fee than that charged by human monks, reflecting changing perceptions in Japan about the role of traditional Buddhist funerals and a growing secular-minded attitude. ${ }^{36}$ Other robots engaging in funeral-related activities are also under development. For instance, neurologist and entrepreneur Fujii Naotaka 藤井直敬 uses a version of Pepper as the prototype for the so-called "Digital Shaman" (dejitaru shāman デジ タルシャーマン). This shaman-like Pepper will have a mask reproducing the facial image of the dead person, and will speak with his or her voice (pre-recorded be-

34 On the situation of robotics in Japan, see Robertson, Robo Sapiens Japonicus.

35 See "Robo-Monk: Sutra-Chanting Doll Becomes Temple Mascot," 1999.5.28, http://web-japan.org/trends00/honbun/tj990527. html.

36 See "Funeral rites of the future" and "Pepper to don monk's robe in new funeral role," The Japan Times, 2017.8.17, https://www. japantimes.co.jp/multimedia/2017/08/17/news/funeral-ritesfuture/. fore death). It will stay with the family of the bereaved for forty-nine days, the traditional period of mourning; on the last day, it will say some final words and shut off. According to Fujii, this limited scope of activity will facilitate the labor of mourning; of course, nothing will prevent future customers from keeping robotic versions of deceased people for a longer time. ${ }^{37}$

A more complex device, called Robo-Priest, has been employed at a Yokohama funerary chapel since 1993. It has been programmed to deliver prayers in ceremonies according to the liturgy of seven Buddhist sects, Shinto, and two Christian denominations. A computer records the date of death of each individual memorialized at the chapel. On that day every year, the Robo-Priest comes down from its location in the chapel's ceiling to a place in front of the altar and chants the appropriate prayers-according to the religion of the deceased person - for thirty minutes. This robot, developed by a commercial, for-profit funeral enterprise, offers customers (the deceased and their families) ritual services that are cheaper and more accurate than those normally offered by Buddhist monks and other religious specialists. ${ }^{38}$ The fact that this robot is customized to pray according to different religious traditions is also noteworthy, as it indicates an emphasis not on the actual person offering the prayers, but on the prayers per se.

An even more high-tech type of memorial service recently has been developed by Shunkeiji 春慶寺 in Oshiage, one of Tokyo's northeastern suburbs. Parishioners can $\log$ on to a specific website, called Netto Nōkotsudō ネット納骨堂 (literally, “internet crypt”), where they can view images of the funerary tablets (ihai 位牌) of their departed relatives and order sutra-chanting for them, in which case they will see a recorded image of a Buddhist priest chanting scriptures for the dead. ${ }^{39}$ The temple's website offers a free demonstration of how the system works. ${ }^{40}$ An additional service is the so-called "computer memorial service" (pasokon kuyō パソコン供養), in which parishioners can view, for a fee (currently, approximately US $\$ 1300$ ), the funerary

37 Nagakura, "Shijūkunichi made wa robotto de issho ni."

38 See Ben Hillis, "The robot priest," http://benhills.com/articles/ japan-unlimited/the-robot-priest/; originally published in the Sydney Morning Herald, 1993.5.4.

39 See Tim Hornyak, "Japanese turning to robotic crypts, virtual grave visits," 2013.4.10, http://www.cnet.com/news/japaneseturning-to-robotic-crypts-virtual-grave-visits/.

40 See http://www.syunkeiji.jp/html/taiken.html. 
tablets of their deceased family members, request and view a virtual sutra-chanting, and also watch a slide show of selected pictures of the deceased. The temple's internet contractor also provides computer installation and support. ${ }^{41}$ This type of funeral service, known as “computer tomb” (dennō haka 電脳墓), is receiving increased interest in Japan. ${ }^{42}$

In addition, companies are developing digital forms of ancestor worship (dejitaru kuyō デジタル供養) for the home. A recent example is the digital-worship set “Fenestra” created by Uriu Daisuke 苽生大輔 at Tōyō University. The set consists of a round digital display resembling a mirror, a digital photo frame, and a candle holder. When a worshipper stands in front of the mirror for a few seconds, an image of the deceased person will appear; similarly, when the candle holder is placed in front of the digital photo frame and the candle is lit, pre-recorded images of the deceased will appear. ${ }^{43}$

Arguably, the development of these kinds of automated services points not so much to a degeneration of Buddhism, but rather to the attempts of Buddhist institutions to address new challenges in contemporary Japanese society - in particular, the growing number of senior citizens (the segment of the population most involved in Buddhist practices) and their reduced mobility, and the increasing fragmentation of Japanese families, with younger people living far from their parents and grandparents and their family tombs. Most Japanese today (and especially Buddhist priests) see Buddhism from a sociologically pragmatic stance that encourages the tradition to adapt to changing social conditions in order to better serve its adherents (but also in order to survive). Automated technologies and the internet make it possible to have religious services available at all times, and from a distance.

The Japanese robotics field is well known for its development of humanoid robots that are engineered to operate in close contact with human beings in the household (as pets, toys, and-in recent prototypeseven as sex objects), in the hospital (as nurses), and in the workplace (as receptionists). In this regard, unlike

41 See http://www.syunkeiji.jp/html/kuyou.html.

42 See Robertson, "Robot Reincarnation," p. 23, and especially Robertson, Robo Sapiens Japonicus; also, Dutei-Ogata, "New Technologies and New Funeral Practices in Contemporary Japan," pp. 227-44. For other recent developments, see the "web butsudan" at http://www.onrain.jp.

43 Nagakura, "Shijūkunichi made wa robotto de issho ni," p. 25. See also www.fenestra.jp. people from other countries, many Japanese show a distinctive interest in, and willingness to interact with, robots. Robert Geraci, among others, explains this is a consequence of Japan's religious heritage: "Valorization of being human in Shinto and Buddhism explains the Japanese preference for humanoid robots." ${ }^{4}$ This supposed "valorization of being human," however, stands in contrast to the lack of differentiation between humans and inanimate entities that we encounter in many aspects of the Japanese religious tradition, as discussed by many authors including Geraci. Geraci and others, moreover, seem to overemphasize, on the one hand, the positive view of technology and robots held by the Japanese, and on the other hand, the negative, dystopian views that supposedly dominate Western visions of robots. Just as motifs such as Frankenstein and authors such as Philip Dick are not representative of the entire range of positions expressed in Europe and America about robots and artificial life, anime characters such as Astroboy, created by Tezuka Osamu 手塚修, and popular robots such as ASIMO (produced by Honda) do not exhaust Japanese attitudes on the subject. The West has a long tradition of visions of a technological, robotic utopia, and Japan has produced some of the most violent and disturbing dystopian visions of a technologically dominated future. ${ }^{45}$

These treatments of attitudes toward Japanese robotics also ignore the distinction between natural entities and man-made artifacts, a distinction that is also present in premodern Japanese philosophical speculation. Such treatments also are characterized by a remarkable confusion between Shinto and Buddhism, and by the vagueness of philosophical arguments regarding issues of materiality and sentience, as we shall see below. ${ }^{46}$

\section{Theoretical Perspectives on Buddhist Prayer Machines}

Elsewhere I have proposed a general classification of ob-

44 Geraci, "Spiritual Robots," p. 10. In this passage, Geraci repeatedly refers to Reader and Tanabe, Jr., Practically Religious, pp. 34-35, 46

45 On this subject, see Gomarasca, "Robottoni, esoscheletri, armature potenziate," pp. 220-62.

46 For an analysis of the cultural and ideological scenarios behind contemporary Japanese robotics, see the recent work by Jennifer Robertson on the subject, in particular her "Gendering Robots," pp. 405-26. 
jects on the basis of their nature and function, by elaborating on the work done by cultural historian Krzysztof Pomian and philosopher Maurizio Ferraris. ${ }^{47}$ The classifications under this system are natural objects (raw objects found by humans in their environment), ideal objects (such as numbers and scientific facts, which do not occupy a place in space and do not depend on subjects for their existence), social objects (such as texts, rituals, and countries), human-made objects (tools, food, and waste), and virtual objects (digital entities). Human-made objects include tools, those objects used to make and modify other objects; machines also belong to this category. These categories are not necessarily distinct and impermeable. A piece of bamboo is a natural object, but it can be worked into a shakuhachi, thus becoming a human-made object; a shakuhachi is also a tool that transforms aspects of the materiality of the Dharma by playing music (a social object). In another set of transformations, a rotating sutra repository can become waste (another type of human-made object) as a consequence of iconoclastic actions, and be recycled as mere pieces of wood (natural objects) ready to be assembled in other configurations (tools).

In the context of this article, this typology allows us to see that Buddhist prayer machines are conceptually amphibious objects, situated as they are at the intersection of human-made objects (artifacts) and social objects (texts): they are tools, made by other tools, used to modify reality by enhancing the human capacity to pray, but they also produce intersubjective sense effects (more or less directly related to their use, functions, and signification) in a broad sense, in uses such as spreading the Dharma and creating ways to understand the teachings and attain salvation. Furthermore, prayer machines are the product of different types of labor: material (the physical labor involved in the transformation of the raw materials and their assembling), semiotic (conceptualization, design, and artistic aspects), ritual (the type of labor that goes into the ritual uses of these machines), and performance (involving the user, other participants, and possible observers). ${ }^{48}$

47 Pomian, "Histoire culturelle, histoire des sémiophores," pp. 82-83; Ferraris, Documentalità. See Rambelli, "Materiality, Labor, and Signification of Sacred Objects in Japanese Buddhism," pp. 5-8.

48 For a preliminary definition of these types of labor, see Rambelli, "Materiality, Labor, and Signification of Sacred Objects," pp. 8-14.
In order to better understand how machines intervene in Buddhist prayer activities, a detour through Umberto Eco's discussion of the various types of objects that extend the natural capacities of the human body is in order here. Eco divides such objects into three distinct groups, which he calls prostheses, instruments, and machines. ${ }^{49}$ Broadly speaking, a prosthesis is "an extension of our body's capacity"; instruments and machines are both prostheses. Prostheses are made by imitating the body and its natural functions, and can be used more or less intuitively; instruments and machines are not modeled after the body. Moreover, instruments require human force to function, whereas machines operate automatically with only minimal human intervention and supervision.

Eco further distinguishes between four types of prostheses, which he calls substitutive, extensive, perfective, and magnifying. A "substitutive prosthesis does what the body used to do but by accident is no longer able to"; this type includes artificial limbs, walking sticks, and eyeglasses. Extensive prostheses "extend the body's natural actions"; they include cups, spoons, chopsticks, and mirrors. Next, perfective prostheses enable the body to accomplish, with a higher degree of perfection, actions that it was already able to carry out naturally; these prostheses include chairs, tables, beds, houses, and stairs. Finally, magnifying prostheses enable the body to perform actions that it would not be able to accomplish by means of its own natural capacities; examples are lenses, telescopes, bicycles, TV sets, and musical instruments.

Instruments (which Eco envisions as operated manually) perform actions that the human body is not able to do; they include knives, scissors, hammers, and even cinema. An important feature of instruments as Eco conceives of them is that they produce new objects and, in so doing, contribute to creating a new reality. Unlike prostheses and instruments, machines do things independently of the bodily organs that they replace or perfect. Moreover, a machine operates by itself, without significant human intervention; often, human beings operating machines do not even know how their mechanisms (and their inner operations) function.

It is possible to envision a continuum, rather than

49 Eco, "Osservazioni sul design del futuro prossimo," pp. 1-4; the following discussion is based mostly on pp. 2-3. On the semiotic value of prostheses, see also Eco, Kant e l'ornitorinco, pp. 317-18. 
clear-cut distinctions, between prostheses, instruments, and machines - a continuum characterized by a gradual abstraction and separation from direct bodily connections. In Eco's interpretation, prostheses are based directly on the shape of the body part that they are enhancing. Instruments are less direct, but their use can still be inferred fairly well by their shape and design. In the case of machines, however, the direct relationship between their function and the human body has disappeared almost completely, being replaced instead by an "interface" such as a button, a keyboard, or a lever. Eco argues that the expanding presence and role of "machines" (as he defines them vis-à-vis prostheses and instruments) in human life might end up dehumanizing our interactions with tools in general. Of course, we may note that dehumanization is being balanced by a counter-tendency to humanize complex machines, including robots, but the potential problem still remains.

In the case of Buddhist machines, however, it may be argued that practically all ritual implements-not only the most complicated apparatuses, but also the simplest tools - are similar to "machine interfaces" in Eco's sense. Their use may be simple and fairly intuitive, but very few users would understand how these devices actually operate and why they are supposed to work. Understanding requires competence in advanced Buddhist doctrine, especially on the status of inanimate objects and the possibility for inanimate entities to spread the Dharma and play a salvific role (which can be either passive or active, according to the interpretation and the tradition). A shakuhachi can be played rudimentarily in a relatively intuitive way, and listeners may associate its sound with Zen Buddhism, but only very few of them will be able to actually spell out why sound-and, in some cases, even noise, including natural noise such as breath and the effects it produces by vibration through the bamboo tube of the instrument-can have a soteriological effect. The same applies to rotating sutra repositories. Paradoxically, however, complex machines such as robots and internet ritual services have been designed to be the easiest to understand and operate.

\section{Doctrinal Issues Related to the Efficacy of Buddhist Prayer Machines}

In order to assess the theoretical role of machines in Buddhism as devices primarily used to spread the Dharma and generate merit, a discussion of both the
Buddhist understanding of what it means to spread the Dharma and of the standard ways to accomplish this through scriptures (and images based on them) is in order. Spreading the Dharma implies not only a quest to win adherents, but also the achievement of various goals, such as the proliferation of material tokens of Buddhism (temples, texts, images, and various types of sacred artifacts), the prosperity of religious institutions, and social respect for Buddhist practitioners. Normally, the diffusion of specific scriptures in ancient and medieval Buddhism took the shape of scripture worship. The Lotus Sutra, one the most influential scriptures in Japanese Buddhism, presents four different and orthodox modes of sutra worship: possession (juji 受持), reading (dokuju 読誦), copying (shakyō 写経), and explaining (gesetsu 解説). ${ }^{50}$ These practices originally comprised means of spreading the teachings, but with the development of the Mahayana tradition, they became fullfledged religious and devotional activities that were believed to produce merit.

Possession (juji) is often translated as "embracing," as indicating a belief in the teachings of the sutra. From the context in which it appears, however, this termliterally meaning "receiving and holding" - should be translated more accurately as "keeping," "owning," or "holding," perhaps with the nuance of "holding dear" but also "remembering." This is the primary mode of scripture worship. To worship a scripture, indeed, the worshipper first must "own" it in some form: as an object, as a memorized series of sounds or graphs, or as a set of teachings.

Reading (dokuju, Sk. svādhyāya, adhyayana) refers to two different forms of "reading" a scripture: a direct reading from the text, either voiced or silent (doku 読); and chanting ( $j u$ 誦) - that is, a memorized form of reading. This distinction in the actualization of the semiotic expression of a scripture-i.e., between reading or listening aimed at understanding, and chanting as a voicing of the written signifier of the text-is particularly important here, because the former is not privileged over the latter. ${ }^{51}$

Sutra copying $($ shakyō) is one of the most distinc-

\footnotetext{
50 Miaofa lianhua jing wen gou 妙法蓮花経文句 (Jp. Myōhō rengekyō mongu), attributed to Zhiyi 智顗 (538-597), contains a description of modes of worshiping the Lotus Sutra; see especially pp. 107c-12c.

51 For a history of sutra chanting with a discussion of its various functions, see Shimizu, Dokyō no sekai.
} 
tive Buddhist devotional practices. In Japan, we find essentially two forms: handwritten copying and printing. Handwritten copying (shakyō proper) consists literally of copying the text onto various materials (usually paper) with a brush. Printing (surikyō 摺り経) historically was carried out by the incision of the characters on wooden boards, which were then painted with ink and finally brayed. ${ }^{52}$

Explaining (gesetsu) is the general term for any kind of commentarial activity on a scripture. This ranges from the practices of itinerant preachers to scholastic teaching, and from exegetical activity to state-sponsored lectures on specific scriptures attended by the emperor and the highest secular authorities; such lectures were included among the official activities conducted for the religious protection of the political system (chingo kokka 鎮護国家).

To summarize, sutra worship as a means of spreading Buddhism consists of various ways to disseminate the material and semiotic aspects of a scripture. Possession is the most general form of sutra worship, as it presupposes the availability of actual copies of the sutra. Reading refers to the proliferation of the phonic signifier, whereas copying is the proliferation of the written signifier. (Here, it is methodologically important to distinguish between a sutra as an object and its two signifiers.) Explaining disseminates the signified of the sutra (its doctrinal content). From this classification, we see that understanding the doctrines of a scripture-that is, the hermeneutic activity - was just one, and perhaps not even the most important, form of sutra worship and source of religious merit.

It is important to note that scripture worship was related to the development of methods and devices used to ensure the broadest possible diffusion of the scriptures/teachings (the Dharma), thus resulting in a maximization of accrued merit. Study and exegesis (the fourth mode of scripture worship), because of their very nature, could only be pursed on an individual basis (or, at most, in small groups). The other forms of worship, in contrast, lent themselves to large-scale endeavors, such as printing (copying) and continuous chanting at busy crossroads (recitation) so as to be heard by many

52 The oldest sutra copy extant in Japan is a copy of the Jinggang chang touluoni jing 金剛場陀羅尼経 (Jp. Kongōjō darani kyō), dating to the fourteenth year of the reign of Emperor Tenmu (686). The practice of surikyō already existed in the Nara period (710-794) people. Tools and technological devices also could be mustered in order to contribute to a more massive and pervasive diffusion of the Dharma by various means.

Now, these modes of Dharma diffusion were focused on spreading not so much the signified of the teachings, but their signifiers. This raises an important doctrinal issue: the intentionality of, and direct participation in, ritual activity aimed at spreading the Dharma. Prayer wheels and rotating sutra repositories, for instance, were built to spread the teachings (their written signifiers) to the four elements, and these devices, in turn, became channels for the diffusion of Buddhism (again, of its signifiers) by giving a concrete, literal form to the image of the Buddha's "turning of the wheel of the Dharma." At the least, the shakuhachi creates a Buddhist atmosphere, but transmission of the Dharma through it is only possible through a non-textual, non-linguistic exegesis of musical signifiers: the musical expression of shakuhachi Zen music cannot be directly and fully translated into verbal doctrines, and ends up creating a music-based Zen experience. Robot and online priests substitute with a virtual reality the traditional need of a direct, physical co-presence of ritual specialist and participant. They are not real monks, only images (on websites) or simulacra (robots). This suggests not only that full ordination of the performer is not important (Japanese Buddhism has a long history of downplaying the role and importance of monastic precepts), but that the emphasis is placed on ritual itself and not on direct performance or attendance; again, the emphasis is on ritual as signifier, not as a set of signifieds. Moreover, we can also detect a trend (already pointed out by Umberto Eco in his discussion of prosthetic devices) towards the diffusion of easy-to-employ digital interfaces as Buddhist prayer machines that require only limited use of the human body in religious activities: no need exists to play the shakuhachi, it is enough to play some digital recordings of it; there is no need to go to a temple to memorialize one's deceased family members, as this can be done from home via personal computer. Direct bodily involvement has always been one of the key features of Buddhist practice, and we may wonder how that will change with the further diffusion of digital technologies and simple interfaces.

In general, scholars tend to present ritual uses of sutras aimed at spreading the Dharma and its benefits as merit-making activities. Especially in contemporary Japan, however, merit does not seem to be a major concern among participants in Buddhist rituals involving 
scripture manipulation. The use of sutras often is considered simply as an activity defined as arigatai ありが たい, a term meaning something valuable, blessed, edifying, or uplifting - something to be appreciated and thankful for. The idea of merit being transferred both to the memorialized person and the sponsors of the ritual is largely absent in Japan today. Still, scriptures are present as material objects (as amulets or paraphernalia in the family's Buddhist altar), and they are "actualized" in rituals through chanting (sound is another "material" form of scriptures). Hence, sutras today (and perhaps, to a certain extent, also in the past) are not used primarily to produce merit; they tend to function as just another liturgical implement, part of the ritual setting. As such, they contribute to creating what we could call a Buddhist "atmosphere," much like design objects and other commodities.

The fact that machines are entrusted with spreading the Dharma raises another important doctrinal issue, an extension of traditional doctrines about "nonsentients preaching the Dharma” (mujō seppō 無情説法), and, more fundamentally, questions about the status of both sentience and the nonsentient. Authors have pointed out that, in the Japanese religious tradition (usually identified with Shintoism), no ontological distinction is made between animate and inanimate beings, humans and machines. Thus, it has been argued that "Shinto acknowledges no necessary contradiction between animism and modern scientism." ${ }^{53}$ As Asakura Reiji has written, "In Japan ... where the native religion sees kami ... in all the myriad manifestations of nature, it follows naturally that a robot would have a spirit as well." ${ }^{\prime 4}$ Perhaps, then, it is not surprising to find out that, in the early phases of the introduction of robots to industrial manufacturing processes, companies hired Shinto priests to perform consecration and naming rituals for the newly installed machines; later, when robots became commonplace in industry, such ceremonies were discontinued. ${ }^{55}$ As recently indicated by Jennifer Robertson, however, a new web-based service was inaugurated in 2014 to provide "robot funerals” (robotto sōロボット葬), mostly aimed at the ritual

53 McFarland, Rush Hour of the Gods, p. 26.

54 Asakura, "The Androids are Coming," p. 18.

55 Schodt, Inside the Robot Kingdom, pp. 196, 197, and 195-212; Henry Scott Stokes, "Japan's love affair with the robot," New York Times, 1982.1.10; Harry W. Clifford, "Japan's robot revolution," New York Times, 1982.2.14 disposal of pet robots (such as Sony's AIBO).$^{56}$ In addition, a Buddhist temple, Kōfukuji 光福寺 in the city of Isumi (Chiba Prefecture) east of Tokyo, has begun to officially perform Buddhist funerals for robotsagain, with a special focus on AIBO pets. For the temple priest, in this ceremony "the robots could pass from their body." 57

One of the most influential proponents of the animated nature of robots is engineer and AI scientist Mori Masahiro, who famously wrote, "robots have the buddha-nature within them - that is, the potential for attaining buddhahood." ${ }^{58}$ Mori argues for the ontological identity of human beings and machines. His starting point is a pantheistic view of the universe, in which a fundamental and eternal life-force permeates all beings and entities. This life-force "forms and moves everything from the elementary particles through ... human beings, society ... to the entire cosmos." ${ }^{.9}$ Mori refers to this basic life-force by the Buddhist term "Emptiness" (Sk. śūnyatā, Jp. kū 空), inaccurately rendered in the English version of the book as "Void." It appears that Mori considers Emptiness to be equivalent to another Buddhist concept, that of the buddha-nature. He writes, "The buddha-nature, then, is the principle or law that moves everything. It exists throughout the universe and fills it completely." ${ }^{\prime \prime}$ Elsewhere, Mori seems to equate the buddha-nature with the Buddha himself, envisioned as the totality of the universe.

It is worth mentioning that, in strictly doctrinal terms, Emptiness is emphatically not a life-force; Mori's interpretation hews closely to modern developments in Japanese Buddhist thought that, in many respects, are not in line with traditional, orthodox doctrines. This modernist pantheism lies at the basis of Mori's argument that robots are also endowed with the buddha-nature and therefore are not different from human beings. According to Mori, machines are created by men, but as men are "appearances created by the Void," by which he means Emptiness or cosmic life-force, "then whatever men create must also be created by the Void. It must also partake of the buddha-nature, so do the rocks and

\footnotetext{
56 See http://robotsou.com.

57 Robertson, "Robot Reincarnation," pp. 13-14. On Kōfukuji's robot funerals, see Suzuki, "An Inside Look at a Japanese Robot Dog Funeral."

58 Mori, The Buddha in the Robot, p. 13.

59 Ibid., p. 112

60 lbid., p. 174
} 
trees around us." ${ }^{61}$ Even more fundamentally, "everything in the universe is identical with the mind of the Buddha." ${ }^{2}$ Thus, continues Mori,

From the Buddha's viewpoint, there is no master-slave relationship between human beings and machines. The two are fused together in an interlocking entity. Man achieves dignity not by subjugating his mechanical inventions, but by recognizing in machines and robots the same buddha-nature that pervades his own inner self. ${ }^{63}$

Despite their overall modernist framework, in which a vague pantheistic and spiritualist animism predominates, Mori's theories are not unrelated to classical Japanese Buddhist doctrinal speculation going back to the ninth century. Mori indeed refers to some Zen teachings as formative of his understanding of the symbiotic relationship between humans and machines. Zen Buddhism developed the idea that nonsentients (objects and natural entities such as trees and mountains) preach the Dharma; words on this subject by the Zen patriarch Dōgen 道元 (1200-1252) are well known. ${ }^{64}$ In East Asian Buddhist thought, the inanimates (mostly, material entities in the environment) normally have been considered to be able to preach the Dharma only to an enlightened person. Another position has maintained that no ontological distinction exists between animate beings and inanimate entities, and thus the latter are also able to preach the Dharma. The argument is that ultimately no distinction is found between subject and object, the enlightened being and his/her own environment; thus the Dharma is not present in specific places (scriptures, temples) or associated with specific people (the Buddha, Zen masters). ${ }^{65}$ Esoteric Buddhism, in both its Shingon and Tendai variants, formulated an analogous doctrine, according to which the entire universe, in all its individual phenomena and entities, is in fact the material body of the cosmic buddha

61 lbid., p. 179

62 Ibid.

63 lbid., pp. 179-80

64 See Dōgen, Shōbōgenzō, vol. 2, pp. 61-71; vol. 1, pp. 331-41.

65 On the status of nonsentients in East Asian Buddhism, with particular attention to Japanese doctrinal developments, see Rambelli, Buddhist Materiality, pp. 11-57; for a brief overview of Japanese views on nature in relation to discussions about nonsentients and sentience, see Rambelli, "Buddhist Environmentalism: Limits and Possibilities," pp. 32-40.
Mahāvairocana. Thus, everything in the universe is part of a cosmic semiotic process of Dharma transmission, called hosshin seppō 法身説法 (the Dharmakāya, i.e., the Buddha in its absolute mode of existence, preaching the Dharma). According to this pansemiotic doctrine, tools (including ritual implements) are one of the four fundamental modes of existence of the cosmic buddha as represented by the karma mandala. ${ }^{66}$

\section{Conclusion}

Thus far, we have seen that Buddhism historically is not against technological advances and their application to religious devices. One of the reasons for this attitude is the effort to promote the Dharma, an effort that requires methods and tools for reproducing and proliferating tokens of Buddhism. The privileged types of Dharma tokens that have been reproduced most extensively through mechanical devices relate directly to the teachings themselves (in a literal understanding of the Dharma), as sanctioned and encouraged by influential Mahayana scriptures, particularly the Lotus Sutra.

It is important to note, though, that this proliferation of tokens of the teachings (Dharma) through mechanical means takes the shape of reproducing and spreading signifiers of Buddhism: copies of the scriptures or of mantras produced by mechanical printing presses, musical sounds associated with Zen Buddhism, ritual forms and appearances as embodied in robots and internet memorial services, and perhaps, in more theoretically problematic forms, the exposure of written signifiers of the scriptures to the four elements as channels for universal diffusion through revolving sutra repositories and prayer wheels in general. In many cases, these types of Dharma machines or their uses were explicitly sanctified and ritualized in order to sanction their use in an orthodox, Buddhist context. This sanctification mobilized doctrines of merit-making by contact with Buddhist tokens, and doctrines of the universal pervasiveness of the Dharma and buddha-nature. One of the consequences of this use of technology for religious purposes, with its almost exclusive focus on signifiers, has been the narcotization of the signifieds (the actual contents of the teachings themselves),

66 On all of this, see Rambelli, A Buddhist Theory of Semiotics, pp. 66-68. 
which have become more vacuous as their connections with their signifiers became more tenuous. ${ }^{67}$ Thus, we observe that, in several cases (and perhaps not only in Japan), the proliferation and presence of Buddhist tokens (signs and symbols) does not necessarily result in a deeper understanding of the Buddhist teachings, but rather contributes to create a kind of Buddhist atmosphere or ambience that may or may not induce people to Buddhistically defined and desirable thought and behavior.

While the creation of a Buddhist atmosphere may be considered a skillful means (Sk. upāya, Jp. hōben 方 便) for the diffusion of Buddhism, it also resonates with another aspect of Buddhism, largely under-recognized, which can be defined as its non-hermeneutical dimension. ${ }^{68}$ This non-hermeneutical dimension actually may be closer to the core of Buddhist teachings than one might expect: with its focus on the direct presence of-and immediate interactions with-materiality, it tries to overcome the dualities that arise from all hermeneutical endeavors, such as sign/referent, signifier/ signified, text/interpreter, and things/words.

In light of all of the above it may be argued that mechanical prayer devices, despite their individual differences (related to the technologies employed, the historical contexts of use, and others), situate themselves at the intersection of received dichotomiessuch as body and technology, material and spiritual, mechanicism and intentionality-and, ultimately, the sacred, salvation, and personal agency, all of which are questioned by the devices. In this sense, the non-hermeneutical product of prayer machines-a mechanically generated interaction with the sacred, the effects of which are almost completely independent of direct human agency and will-is something that transcends any dualistic distinctions (because it makes them irrelevant); as such, it is perhaps the ultimate form of Buddhist prayer.

67 The opposite also could be argued; namely, that because the Buddhist teachings are so complex and hard to master, the circulation of even simple understandings is important for the spread of Buddhism.

68 On the non-hermeneutical dimension of Buddhism, see Rambelli, Buddhist Materiality, pp. 89, 126-28, 259-73; Rambelli, "Materiality, Labor, and Signification," pp. 18-19.

\section{Reference List}

Adas, Michael. Machines as the Measure of Men: Science, Technology, and Ideologies of Western Dominance. Cornell University Press, 1989.

Asakura, Reiji. “The Androids are Coming." Japan Echo 30:4 (2003), pp. 13-18.

Conlan, Thomas. "Instruments of Change." In War and State Building in Medieval Japan, ed. John Ferejohn and Frances Rosenbluth, pp. 124-58. Stanford University Press, 2010.

Dairyū 大龍. Sanken itchisho 三賢一致書 (also known as Sangai isshinki 三界一心記). In vol. 5 of Nihon shisō tōsō shiryō 日本思想闘争史料, ed. Washio Junkei 鷲尾順敬, pp. 503-40. Meicho Kankōkai, 1969-1970.

Dōgen 道元. Shōbōgenzō 正法眼蔵. In Dōgen. NST 12-13.

Dutei-Ogata, Fabienne. "New Technologies and New Funeral Practices in Contemporary Japan.” In Asian Religions, Technology and Science, ed. Istváan Keul, pp. 227-44. London: Routledge, 2015.

Eco, Umberto. Kant e l'ornitorinco. Milan: Bompiani, 1997.

Eco, Umberto. "Osservazioni sul design del futuro prossimo.” DDD Colore. Rivista trimestrale Disegno e Design Digitale 6, pp. 1-4.

Eubanks, Charlotte. "Circumambulatory Reading: Revolving Sutra Libraries and Buddhist Scrolls." Book History 13 (2010), pp. 1-24.

Ferraris, Maurizio. Documentalità. Rome and Bari: Laterza, 2009. English translation: Documentality. Fordham University Press, 2012.

Furukawa Miki 古河三樹. Zusetsu shomin geinō: Edo no misemono 図説庶民芸能: 江戸の見世物. Yūzankaku, 1982.

Geraci, Robert M. "Spiritual Robots: Religion and Our Scientific View of the Natural World." Theology and Science 4:3 (2006), pp. 229-46.

Gomarasca, Alessandro. "Robottoni, esoscheletri, armature potenziate: Le metafore del meka-corpo nell'animazione giapponese." In La bambola e il robottone: Culture pop nel Giappone contemporaneo, ed. Alessandro Gomarasca, pp. 220-62. Torino: Einaudi, 2001.

Goodrich, Luther C. "The Revolving Bookcase in China." HJAS 7 (1942), pp. 130-65.

Gutzwiller, Andreas. Die Shakuhachi der Kinko-Schule. Vol. 5 of Studien zur Traditionellen Musik Japan. Kassel: Bärenreiter, 1983.

Gutzwiller, Andreas. "Shakuhachi: Aspects of History, Practice and Teaching." PhD dissertation, Wesleyan University, 1974. 
Johnson, Henry. Shakuhachi: Roots and Routes. Leiden and Boston: Brill, 2014.

Kanze Nagatoshi 観世長俊, attributed. Rinzō 輪蔵. In vol. 5 of Yōkyoku taikan 謡曲大観, ed. Sanari Kentarō 佐成謙 太郎, pp. 3373-84. Meiji Shoin, 1963-1964.

Kinoshita Naoyuki 木下直之. Bijutsu to iu misemono: Aburae jaya no jidai 美術という見世物: 油絵茶屋の時 代, Kōdansha, 2010.

Kornicki, Peter. "The Hyakumantō Darani and the Origin of Printing in Eighth-Century Japan.” International Journal of Asian Studies 9:1 (2012), pp. 43-70.

McFarland, H. Neill. Rush Hour of the Gods: A Study of New Religious Movements in Japan. New York: MacMillan, 1976.

Mori, Masahiro. The Buddha in the Robot: A Robot Engineer's Thoughts on Science and Religion. Kosei, 1999.

Nagakura Katsue 長倉克枝. “Shijūkunichi made wa robotto de issho ni”四十九日まではロボットで一緒に. AERA, 2017.8.7, pp. 24-25.

Nishimura Shigenaga 西村重長. Ōkarakuri etsukushi 大か らくり絵尽. 2 vols. Kōzandō, 1933.

Pomian, Krzysztof. "Histoire culturelle, histoire des sémiophores.” In Pour une histoire culturelle, ed. Jean-Pierre Rious and Jean-François Sirinelli, pp. 83-10o. Paris: Seuil, 1997.

Rambelli, Fabio. "Buddhist Environmentalism: Limits and Possibilities." Poetica 80, special issue on "Japan and Ecocriticism," ed. David Bialock and Ursula Heise (2014), pp. 21-49.

Rambelli, Fabio. Buddhist Materiality: A Cultural History of Objects in Japanese Buddhism. Stanford University Press, 2007.

Rambelli, Fabio. "Honji Suijaku at Work: Religion, Economics, and Ideology in Pre-Modern Japan." In Buddhas and Kami in Japan: Honji Suijaku as a Combinatory Paradigm, ed. Mark Teeuwen and Fabio Rambelli, pp. 255-81. London and New York: RoutledgeCurzon, 2003.

Rambelli, Fabio. "Materiality, Labor, and Signification of Sacred Objects in Japanese Buddhism." Journal of Religion in Japan 6:1 (2017), pp. 1-26.

Rambelli, Fabio. "Sacred Objects and Design in Buddhism." In vol. 4 of World Encyclopedia of Design. London: Bloomsbury, forthcoming.

Rambelli, Fabio. "Sada Kaiseki: An Alternative Discourse on Buddhism, Modernity, and Nationalism in the Early Meiji Period." In Politics and Religion in Japan: Red Sun, White Lotus, ed. Roy Starrs, pp. 104-42. London: Palgrave MacMillan, 2011.
Rambelli, Fabio. "Visions of the Invisible: Images and Representations in the Buddhist Tradition." In Images and Visions in Christian and Buddhist Culture, ed. Akira Akiyama and Kana Tomizawa (Kitazawa), pp. 132-43, 147-48. Special issue of Bulletin of Death and Life Studies 8. Global COE Program DALS, Graduate School of Humanities and Sociology, The University of Tokyo, 2012. Reader, Ian, and George J. Tanabe, Jr. Practically Religious. University of Hawai'i Press, 1999.

Robertson, Jennifer. "Gendering Robots: Posthuman Traditionalism in Japan." In Recreating Japanese Men, ed. Sabine Frühstück and Anne Walthall, pp. 405-26. University of California Press, 2011.

Robertson, Jennifer. Robo Sapiens Japonicus: Robots, Gender, Family, and the Japanese Nation. University of California Press, 2017.

Robertson, Jennifer. "Robot Reincarnation: Garbage, Artifacts, and Mortuary Rituals." In Consuming Post-Bubble Japan, ed. Ewa Machotka and Katarzyna Cwiertka. Amsterdam University Press, forthcoming.

Schodt, Frederik L. Inside the Robot Kingdom: Japan, Mechatronics, and the Coming Robotopia. New York: Kodansha International, 1988.

Schopen, Gregory. Figments and Fragments of Mahayana Buddhism in India. University of Hawai'i Press, 2005.

Shimizu Masumi 清水眞澄. Dokyōno sekai 読経の世界. Yoshikawa Kōbunkan, 2001.

Simpson, William. The Buddhist Praying-Wheel: A Collection of Material Bearing Upon the Symbolism of the Wheel and Circular Movements in Custom and Religious Ritual. London and New York: MacMillan, 1896.

Suzuki, Miwa. "An Inside Look at a Japanese Robot Dog Funeral." 2015. https:/www.yahoo.com/tech/an-insidelook-at-a-japanese-robot-dog-funeral-112049680289. html.

Takahashi Kūzan 高橋空山. Fukeshū shōshi: Sono shakuhachi sōhō no gakuri 普化宗小史: その尺八奏法の楽理. Fukeshūshi Kankōkai, 1979.

Tatsukawa Shōji 立川昭二. Karakuri からくり. Vol. 3 of Mono to ningen no bunkashi ものと人間の文化史. Hōsei Daigaku Shuppankyoku, 1969.

Travagnin, Stefania. “Cyber-Activities and 'Civilized' Worship: Assessing Contexts and Modalities of Online Ritual Practices." In Buddhism After Mao: Negotiations, Continuities and Reinventions, ed. Gareth Fisher, Ji Zhe, and Andre Laliberte. Forthcoming.

Vallverdú, Jordi. "The Eastern Construction of the Artificial Mind." Enrahonar. Quaderns de Filosofia 47 (2011), pp. $171-85$. 
White, Lynn T. Medieval Religion and Technology: Collected Essays. University of California Press, 1978.

Zhiyi 智顗. Miaofa lianhua jing wen gou 妙法連華経文句.

T 1718, 34: 1-149. 